\title{
Waterbird flight initiation distances at Barberspan Bird Sanctuary, South Africa
}

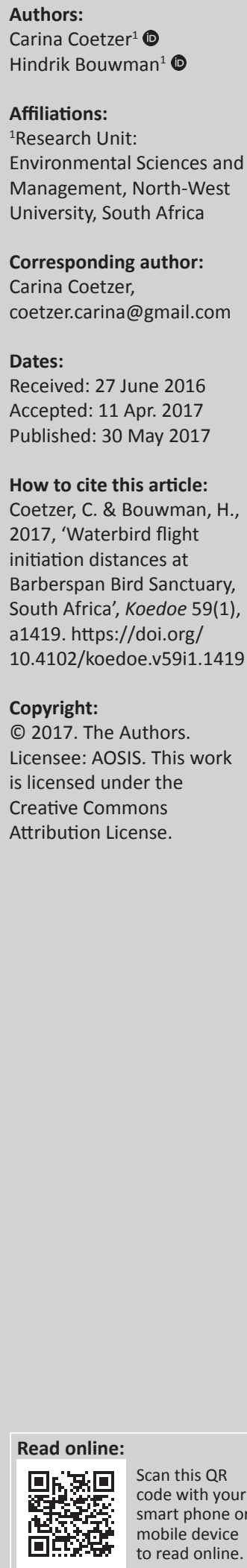

With tourism in South Africa expanding, the number of avitourists increases. The increase in infrastructure and human activities in protected areas, if not managed properly, can be harmful to birds. Flight initiation distances (FID) can be used as a method to monitor habituation to disturbances. This study was performed at the Barberspan Bird Sanctuary, North West province, South Africa, to determine the levels of habituation among waterbirds and make appropriate recommendations regarding the management of the reserve. Our results indicated a $0.29 \mathrm{~m}$ increase in FID per gram reported mean biomass. Compared with conspecific or congeneric birds from Australia, Europe and North America, South African birds have relatively larger FIDs to human disturbance, which may indicate lower habituation. We also calculated buffer zones based on the maximum FID of the waterbirds for three mass groups. These buffer zones were then matched with the spatial distribution of the birds along the shoreline. We recommend that the mean FID for the blacksmith lapwing, Vanellus armatus (62 $\mathrm{m})$, can be used as approach distance outside the breeding season in areas where the birds are sparsely distributed and $104 \mathrm{~m}$ during the breeding season in breeding areas. A large buffer of $200 \mathrm{~m}$ is suggested for areas with threatened, sensitive and skittish species. However, it is still preferable for avitourists to use the bird hides along the shores.

Conservation implications: This study provides information for conservation management at Barberspan, based on typical birder activity. Smaller birds would need smaller buffer zones, while larger birds need much greater distances from observers to minimise disturbance. Similar studies can be applied elsewhere.

\section{Introduction}

South Africa is an ecotourism hotspot, with large numbers of international and local tourists visiting its numerous parks and reserves. When the number of tourists visiting South Africa increases, avitourists (birdwatchers) will also increase, as South Africa hosts a large variety of species, habitats, and botanical centres of endemism (Biggs et al. 2011). This influx of human activity into protected natural areas, if not managed properly, can be harmful to the resident wildlife and have far-reaching effects on the future of that area as an ecotourism destination.

Flight initiation distances (FID) can be defined as the distance at which an individual bird approached by a predator or threat initiates flight, and can be used to determine the degree of habituation of avian species in a protected area (Blumstein 2003, 2006). There are various terminologies used in the literature on distances that birds may be approached at, such as buffer zone, set-back distance and approach distance (Blumstein et al. 2003; Madsen 1998; Mcleod et al. 2013; Rodgers \& Smith 1995). Here, we consider the use of approach distances (for individual birds) and buffer zones (for specific areas) to be appropriate.

Fleeing generally occurs when the costs and benefits are optimised. This is known as the Optimal Escape Theory (Møller \& Tryjanowski 2014; Stankowich \& Blumstein 2005). Costs may include decreased time for nest building or foraging (Møller et al. 2013a; Møller \& Tryjanowski 2014) and consequently poorer health in certain species if the situation is not remedied (Kerbiriou et al. 2009; Møller 2010; Møller \& Liang 2012). FID is a species-specific trait (Blumstein et al. 2003) and can, therefore, be used to determine the effect of disturbances on species, including rare or vulnerable species. It should, however, be mentioned that FID is also dependent on other factors such as flock size, speed of approach, distance to and availability of safe structures, starting distance (the distance from which the predators or humans begin to approach the individual or group) and type of disturbance (Blumstein 2003, 2006; Cooper 2005; Dugatkin 2009; Geist et al. 2005; Kullberg \& Lafrenz 2007; McLeod et al. 2013). 
As birds habituate to human activities in specific areas such as urban and recreational areas, their FIDs will shorten and allow them to coexist with humans (Møller et al. 2013a). However, in a bird sanctuary or reserve, it is generally deemed undesirable for birds to habituate, as the disruption in foraging time and the increased stress levels in the birds can lead to decreased biomass (Borgmann 2011; Kerbiriou et al. 2009; Rodgers \& Smith 1995). Some birds, like the Goliath Heron Ardea goliath, also generally avoid any man-made structures (Hockey, Dean \& Ryan 2005), limiting them to sanctuaries and mostly natural areas. Some species numbers are, although globally listed as least concerned, declining because of human disturbances, including pollution. These species include the Yellow-billed Stork Mycteria ibis (which is Near Threatened in South Africa) and the African Darter Anhinga rufa (Hockey et al. 2005). It should be noted that there are opposing opinions concerning habituation. Goering and Cherry (1971) found disturbance to have no significant effects on breeding success, and Nisbet (2000) suggests that habituation to humans should be promoted in waterbirds, as he found no evidence of human disturbances causing substantial harm to gulls (Larus spp.), terns (Sterna spp.) and herons (Ardeidae). Hockey et al. (2005) also mention that the numbers of several species have increased because of manmade structures creating more habitat areas for them to occupy. Some of these species include the Three-banded Plover Charadrius tricollaris and Hadeda Ibis Bostrychia hagedash. Gill, Norris and Sutherland (2001) suggest that if birds avoid disturbance in an area, it does not necessarily have a negative consequence at the population level. They might only be avoiding the disturbance because they have access to a better site in the near vicinity.

Anthropogenic disturbances should, therefore, be well managed to allow sufficient time for foraging and nest building by birds, but it is not completely necessary to terminate all human activity in order to preserve the natural quality of the area. For that reason, it is necessary to study the FIDs of birds to determine their level of habituation to disturbances (McLeod et al. 2013). Once the FIDs of species are determined in a reserve or sanctuary, buffer zones for recreation, approaches, and other human activities can be established for better conservation of the habitats (Blumstein et al. 2003; McLeod et al. 2013).

The aim of this study was to determine the FIDs of the waterbirds at Barberspan Bird Sanctuary and propose buffer zones accordingly to ensure better management of the site as a bird sanctuary.

\section{Materials and methods}

\section{Study site}

This study was conducted at Barberspan Bird Sanctuary $\left(26^{\circ} 35^{\prime} \mathrm{S} 25^{\circ} 35^{\prime} \mathrm{E}\right), 307 \mathrm{~km}$ west of Johannesburg, between Sannieshof and Delareyville. This is a summer rainfall area with annual rainfall averaging around $500 \mathrm{~mm}$. The daily mean minimum and maximum temperatures during summer are $15^{\circ} \mathrm{C}$ and $30^{\circ} \mathrm{C}$, respectively, and during winter $0{ }^{\circ} \mathrm{C}$ and
$20{ }^{\circ} \mathrm{C}$ (South African Weather Service data). Barberspan was one of the first (1975) wetlands in South Africa to be designated a Wetland of International Importance (Ramsar site) and represents a rare and unusual type of perennial wetland, that is, a large grassland pan. The water surface covers approximately 2000 ha and only has an overflow during high water levels, making the water of the pan alkaline because of evaporation. It functions as an important seasonal stopover site for migrating waterbirds and provides sanctuary for moulting waterbirds (Milstein 1975; Ndlovu et al. 2013). Of great importance is its provision of perennial water in an area characterised by seasonal wetlands (Milstein 1975). There is no hunting allowed in the reserve. A mean of 3052 tourists visit Barberspan annually but less than 10\% are strictly birdwatchers, while the remaining $90 \%$ are anglers or tourists passing through the area to another destination (Van der Merwe, S., 2016, email, 08 September, barbersp@lantic.net). Between April 2013 and March 2014, 3243 people in 1393 vehicles visited the reserve.

More than 350 aquatic and terrestrial bird species have been recorded. The pan sometimes holds over 20000 birds (Bouwman \& Hoffman 2007). During the July 2014 Coordinated Waterbird Counts (CWAC), 6858 individuals representing 44 waterbird species were observed (CWAC report, July 2014, Van der Merwe, S., 2016, email, 05 September, barbersp@lantic.net). FIDs were measured in all accessible areas around the pan, including the frequently used general angling area on the eastern shore, the infrequently used competition angling area and the nature reserve covering the whole of the western shore. The latter area is a no-angling area and is strictly for the use of hikers and birders. These localities with varying numbers of visitors enabled us to get a general view of the birds' habituation at Barberspan.

\section{Data collection and analysis}

Flight initiation distances fieldwork was conducted in 5-day sessions, once in a month, for 3 months (March, April, and July 2014) as these autumn months include a high number of both resident and some migratory waterbird species. Observations were made, and FIDs were recorded from an hour after sunrise for $3 \mathrm{~h}$ (06:30-09:30), and again $2 \mathrm{~h}$ before sunset until sunset (16:00-18:00). FIDs were measured by identifying the bird from as far away as possible, and taking a starting distance with a Leica Rangemaster 1200 laser range finder. Two or three observers approached the birds, wearing dark-coloured clothing for uniformity and consistency, and walking abreast so as to not appear as only one person (Geist et al. 2005; McLeod et al. 2013). The mean height of the observers was $1.8 \mathrm{~m}$. If birds were in a group, a focal, visible individual at the edge of the group was selected to measure starting distance and FID. The bird was approached head-on and in a straight line at a leisurely walking pace $( \pm 2 \mathrm{~km} / \mathrm{h})$. The birds were not stalked but approached in the open, which the flat and open terrain of Barberspan allowed for. FID was taken as soon as the bird took flight because of the observers. In our case, we assumed that the obvious interest 
shown by the approaching humans by looking and pointing things at them (heads, binoculars, fingers, and the laser range finder; see also Bateman \& Fleming 2011) was perceived as threats by the birds being approached. Any flight because of obvious relocation for foraging or other disturbances was not recorded. Mean body mass of each species was used as a reference to FID as it was previously found to correlate with FID (Møller \& Erritzøe 2010; Møller, Vagasi, \& Pap 2013b). The mean mass of the species was obtained from Del Hoyo, Elliot and Sargatal (1992, 1996, 2004).

Data for species with more than five FID observations were used (33 species, for a total of 525 records) for univariate analyses. The untransformed data were analysed in GraphPad PRISM v5.04 (http:/ / www.graphpad.com) using linear regression and column statistics. Linear regression was used to investigate the correlation between mass and FID. One-phase decay was used to plot FID versus starting distance, with outliers eliminated ( $1 \%$ and $99 \%$ percentiles). A non-linear, one-phase decay model was chosen assuming that the rate at which FID increases is proportional to an increase in starting distance (http:/ / www.graphpad.com).

Buffer zones were calculated by using the maximum FID for species in arbitrarily chosen mass classes, namely small (less than $200 \mathrm{~g}$ ), medium (201 g - $1000 \mathrm{~g}$ ), and large birds (more than $1000 \mathrm{~g}$ ). Although several authors (Borgmann 2011; Rodgers \& Smith 1995) suggest using only or mostly the most sensitive or skittish species to establish buffer zones (or setback distances), we combined data for all species as this represents the actual situation on the ground, as Barberspan may be merely a stopover site for some of the skittish and rare birds. Using this combination allowed for better accommodation of all species when proposing a buffer zone.

\section{Results}

We generated 525 individual FIDs over 30 sessions divided equally between dawn and dusk sessions. The biomass of the different species varied over two orders of magnitude $(21 \mathrm{~g}-4330 \mathrm{~g})$. The mean FIDs for both families that were the most common and the different mass classes of the birds at Barberspan are presented in Table 1. Generally, larger bird species had greater FIDs (Table 1). Species

TABLE 1: Mean flight initiation distance $(\mathrm{m})$ with standard deviation for the most common waterbird families and mass classes found at Barberspan.

\begin{tabular}{lcc}
\hline Most common families & Number of species & Mean FID (m) \pm s.d. \\
\hline Ardeidae & 7 & $101 \pm 27$ \\
Anatidae & 6 & $70 \pm 23$ \\
Phalacrocoracidae & 2 & $84 \pm 2$ \\
Threskiornithidae & 3 & $78 \pm 17$ \\
Charadriidae & 4 & $44 \pm 19$ \\
Mass classes (g) & & \\
$0-100$ & 6 & $34 \pm 9$ \\
$101-200$ & 4 & $49 \pm 13$ \\
$201-500$ & 5 & $74 \pm 20$ \\
$501-1000$ & 7 & $75 \pm 19$ \\
$1001-1500$ & 5 & $85 \pm 20$ \\
$1501+$ & 6 & $115 \pm 30$ \\
\hline
\end{tabular}

FID, flight initiation distance; s.d., standard deviation. with mean FIDs less than $40 \mathrm{~m}$ were waders (families Charadriidae, Recurvirostridae, Scolopacidae, Motacillidae and Podicipedidae), while species with mean FIDs greater than $100 \mathrm{~m}$ included five Ardeidae species and the lesser flamingo Phoenicopterus minor. The shortest FID was for the Three-banded Plover at $7 \mathrm{~m}$, while the greatest FID was for the Goliath Heron at $300 \mathrm{~m}$. A summary of the minimum, maximum, mean, and median FIDs, including the starting distance and coefficient of variation (CV), for 33 waterbird species at Barberspan is presented in Table 2. Table 2 also shows comparable FID data (conspecific or congeneric) from Blumstein (2006).

There was no normal distribution of all FIDs combined (Figure 1a), neither for the log-transformed data, so we used untransformed data as it describes a normal situation to be faced in a water body such as Barberspan. A mean FID of $73.5 \mathrm{~m}$ was derived with a standard deviation of $43.5 \mathrm{~m}$; the upper standard deviation (s.d.) was at $125 \mathrm{~m}$. The $95 \%$ confidence intervals of the mean were very narrow around the mean, between $70 \mathrm{~m}$ and $77 \mathrm{~m}$.

Because most species-specific FID data were normally distributed according to the Shapiro-Wilk normality test, they were not transformed for regression analyses. Various non-linear models were fitted, but linear regression produced the best results (Figure $1 \mathrm{~b}$ and $\mathrm{d}$ ). One-phase decay gave the best results for regressing FID versus starting distances (Figure 1d).

Mass influenced FID positively (Figure 1b) using linear regression $\left(R^{2}=0.3928 ; p<0.0001\right)$. For every gram of mass increase, there was a corresponding $0.29 \mathrm{~m}$ increase in FID. The CVs of the FIDs were normally distributed (Figure 1c). The mean CV for all species was $37.5 \%$, with a standard deviation of $10.3 \%$. The starting distances influenced the FID markedly $\left(R^{2}=0.6581\right)$ using a one-phase decay model (Figure 1d). Nine outliers were excluded as they exceeded the $1 \%$ percentile. The plateau was reached at $246 \mathrm{~m}$, after which the increase in starting distances did not affect FID.

\section{Discussion and recommendations Flight initiation distance}

For the relatively small area sampled and the good visibility, we assumed that our sample (consisting of the 33 species recorded more than five times) was representative of the occurrence of the species at Barberspan. However, larger, more conspicuous birds, such as the Goliath Heron, would attract more attention per individual than smaller birds per sampling effort and there may be a bias towards the larger birds. The smaller waders and ducks are not restricted to open habitat, as some (such as the red-billed teal Anas erythrorhyncha and threebanded plover) can also be found in or near areas with more vegetation along the shoreline. A shorter FID, allowed for by the ability to quickly escape, makes it safer for them to venture here. The taller birds would be less restricted by obstructive vegetation, because a higher eye height would allow the farther detection of bigger prey items and threats (Blumstein 2006). 
TABLE 2: Flight initiation distances for 33 waterbird species at Barberspan.

\begin{tabular}{|c|c|c|c|c|c|c|c|c|c|}
\hline $\begin{array}{l}\text { Common names of sampled } \\
\text { species }\end{array}$ & Scientific names & Mass (g) & $\begin{array}{l}\text { Number of } \\
\text { records }\end{array}$ & $\begin{array}{l}\text { Mean } \\
\text { FID (m) }\end{array}$ & $\begin{array}{c}\text { Min } \\
\text { FID }(m)\end{array}$ & $\begin{array}{c}\text { Max } \\
\operatorname{FID}(m)\end{array}$ & $\begin{array}{l}\text { Median } \\
\text { FID (m) }\end{array}$ & $\begin{array}{l}\text { Starting } \\
\text { distance }\end{array}$ & $\% \mathrm{CV}$ \\
\hline Cape wagtail & Motacilla capensis & 21 & 8 & 32 & 12 & 73 & 25.5 & 67 & 59 \\
\hline White wagtail* & Motacilla alba & - & - & 8 & - & - & - & - & - \\
\hline Little stint & Calidris minuta & 25 & 16 & 32 & 12 & 64 & 26 & 50 & 52 \\
\hline Least sandpiper* & Calidris minutilla & - & - & 9 & - & - & - & - & - \\
\hline Three-banded plover & Charadrius tricollaris & 33 & 15 & 24 & 7 & 70 & 22 & 53 & 60 \\
\hline Kittlitz's plover & Charadrius pecuarius & 36 & 40 & 33 & 12 & 74 & 30.5 & 56 & 38 \\
\hline Red-capped plover* & Charadrius ruficapillus & - & - & 22 & - & - & - & - & - \\
\hline Curlew sandpiper & Calidris ferruginea & 64 & 5 & 32 & 26 & 42 & 27 & 67 & 25 \\
\hline White-winged tern & Chlidonias leucopterus & 80 & 16 & 52 & 30 & 99 & 49 & 79 & 36 \\
\hline Little grebe & Tachybaptus ruficollis & 146 & 8 & 40 & 21 & 59 & 39 & 77 & 32 \\
\hline Australasian grebe* & Tachybaptus novaehollandiae & - & - & 23 & - & - & - & - & \\
\hline Blacksmith lapwing & Vanellus armatus & 163 & 54 & 62 & 20 & 188 & 56 & 97 & 47 \\
\hline Black-winged stilt & Himantopus himantopus & 167 & 11 & 37 & 15 & 68 & 32 & 87 & 26 \\
\hline Crowned lapwing & Vanellus coronatus & 175 & 11 & 57 & 35 & 76 & 63 & 87 & 26 \\
\hline Masked lapwing* & Vanellus miles & - & - & 47 & - & - & - & - & - \\
\hline Squacco heron & Ardeola ralloides & 248 & 10 & 61 & 34 & 89 & 61.5 & 94 & 31 \\
\hline Grey-headed gull & Larus cirrocephalus & 280 & 7 & 65 & 24 & 102 & 71 & 105 & 54 \\
\hline Black heron & Ardea melanocephala & 313 & 5 & 104 & 54 & 195 & 92 & 119 & 52 \\
\hline Western cattle egret & Bubulcus ibis & 372 & 5 & 85 & 41 & 174 & 71 & 167 & 61 \\
\hline Cape teal & Anas capensis & 402 & 8 & 57 & 42 & 104 & 48.5 & 74 & 37 \\
\hline Little egret & Egretta garzetta & 532 & 6 & 92 & 59 & 128 & 91.5 & 184 & 24 \\
\hline Little egret* & Egretta garzetta & - & - & 52 & - & - & - & - & - \\
\hline Reed cormorant & Phalacrocorax africanus & 555 & 29 & 85 & 22 & 200 & 77 & 145 & 51 \\
\hline Little black cormorant* & Phalacrocorax sulcirostris & - & - & 24 & - & - & - & - & - \\
\hline Cape shoveler & Anas smithii & 571 & 5 & 44 & 31 & 81 & 38 & 89 & 39 \\
\hline Grey teal* & Anas gracilis & & & 42 & & & & & \\
\hline Red-billed teal & Anas erythrorhyncha & 593 & 33 & 57 & 27 & 120 & 53 & 93 & 39 \\
\hline Red-knobbed coot & Fulica cristata & 737 & 37 & 97 & 32 & 213 & 85 & 134 & 46 \\
\hline Southern pochard & Netta erythropthalma & 818 & 12 & 69 & 36 & 124 & 63 & 114 & 42 \\
\hline Yellow-billed duck & Anas undulata & 894 & 26 & 87 & 38 & 196 & 84.5 & 124 & 42 \\
\hline Great egret & Egretta alba & 1100 & 15 & 102 & 51 & 141 & 105 & 175 & 25 \\
\hline Great egret* & Ardea alba & - & - & 73 & - & - & - & - & - \\
\hline African darter & Anhinga rufa & 1245 & 16 & 76 & 25 & 133 & 70.5 & 149 & 36 \\
\hline Darter* & Anhinga melanogaster & - & - & 24 & - & - & - & - & - \\
\hline Hadeda ibis & Bostrychia hagedash & 1280 & 18 & 67 & 37 & 99 & 71 & 132 & 31 \\
\hline Grey heron & Ardea cinerea & 1435 & 7 & 112 & 90 & 147 & 107 & 195 & 17 \\
\hline Great blue heron* & Ardea herodias & - & - & 37 & - & - & - & - & - \\
\hline Sacred ibis & Threskiornis aethiopicus & 1500 & 5 & 69 & 36 & 112 & 60 & 138 & 42 \\
\hline Australian white ibis* & Threskiornis molucca & - & - & 32 & - & - & - & - & - \\
\hline African spoonbill & Platalea alba & 1620 & 10 & 98 & 45 & 147 & 100 & 162 & 34 \\
\hline Royal spoonbill* & Platalea regia & - & - & 44 & - & - & - & - & - \\
\hline Lesser flamingo & Phoenicopterus minor & 1725 & 6 & 157 & 85 & 204 & 126.5 & 226 & 36 \\
\hline White-breasted cormorant & Phalacrocorax lucidus & 1780 & 9 & 83 & 52 & 139 & 87 & 138 & 33 \\
\hline Great cormorant* & Phalacrocorax carbo & - & - & 32 & - & - & - & - & - \\
\hline Yellow-billed stork & Mycteria ibis & 2000 & 17 & 99 & 45 & 160 & 96 & 162 & 30 \\
\hline Egyptian goose & Alopochen aegyptiaca & 2110 & 17 & 108 & 58 & 205 & 116 & 171 & 34 \\
\hline Goliath heron & Ardea goliath & 4330 & 29 & 148 & 66 & 300 & 127 & 213 & 37 \\
\hline
\end{tabular}

Note: Species are arranged according to their mean biomass.

FID values in bold emphasise the difference between local and Australasian species' FIDs.

$\mathrm{CV}$, coefficient of variation; FID, flight initiation distance.

*, Conspecific or congeneric Australasian species to the species mentioned directly above, obtained from Blumstein 2006

Some of the species we observed, especially those favouring the frequently used angling area, seemed to be partially habituated to humans. FIDs reported for Australian, European and American conspecifics and congenerics (Blumstein 2006) were consistently shorter than at Barberspan, and some by a quite a large margin (Table 2). The large FIDs measured at Barberspan Bird Sanctuary may be accounted for by two interacting reasons. Firstly, black-backed jackal Canis mesomelas, Cape clawless otter Aonyx capensis, caracal Felis caracal, small-spotted genet Genetta genetta, a variety of mongooses, and many raptors (including African Fish Eagle Haliaeetus vocifer, taking ducks and flamingos; H. Bouwman, pers. obs.) also occur at the Barberspan Bird Sanctuary. These are all known predators of birds. This occurrence of 


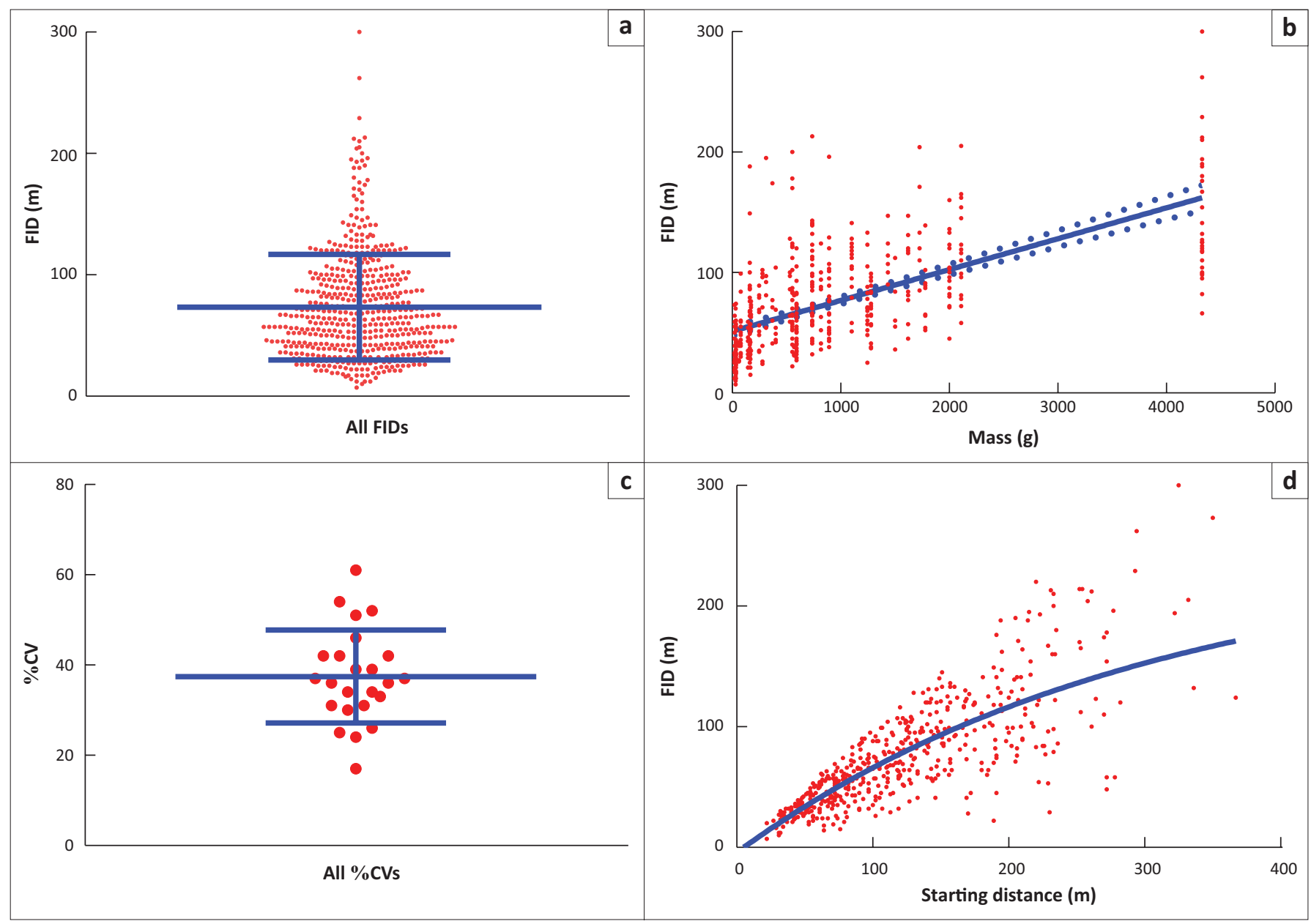

Horizontal lines in (a) and (c) represent mean and standard deviation confidence intervals.

FIGURE 1: (a) All recorded flight initiation distances, irrespective of species. (b) Linear regression of flight initiation distances relative to bird mass. (c) Coefficient of variation (\%) for all species. (d) Non-linear (one-phase decay) regression of mass and flight initiation distances and starting distances.

fast-moving predators might contribute to the longer FIDs when compared with congenerics and conspecifics elsewhere (Blumstein 2006; Table 2). Møller and Liang (2012) predicted and found that species in tropical areas take smaller risks (therefore longer FIDs) than the same or closely related species in temperate areas. According to them, this effect was not only related to predation pressure, possibly being greater in tropical areas, but also to life-history traits, especially clutch size. Tropical birds live longer, produce smaller clutches and start breeding at a later age. Therefore, they should be more risk-averse than their temperate counterparts (Møller \& Liang 2012).

The species CVs were normally distributed (Figure 1c), and the regression between $\mathrm{CV}$ and mass was not significant ( $p=0.0711$ ), indicating a set of common factors that birds, irrespective of species, consider when perceiving and reacting to threats. Describing these factors will need more research.

Our results confirm those of Blumstein (2003) and Cooper (2005), namely that FID and starting distances are not linearly related (see Figure $1 \mathrm{~d}, R^{2}=0.6581$ ). Beyond a certain distance, an increase in mean starting distances does not seem to affect FID, and therefore, one-phase decay was an appropriate model. Distances longer than $246 \mathrm{~m}$ (the plateau) is very long and visual acuity and observation skills of the observers may become a factor.

\section{Conservation management}

Nature reserves dedicated to mostly birdwatching such as Barberspan should be managed with least possible disturbance to the birds, while allowing birdwatchers good and unobstructed views and minimising disturbance to birds.

Figure 1a shows that the upper standard deviation of the mean of all observations was $125 \mathrm{~m}$. Not approaching any bird by less than $125 \mathrm{~m}$ would protect against most disturbances, but would still affect the larger birds such as the Goliath Heron. However, birds are not distributed evenly around Barberspan because of large differences in vegetation, shallows, wind and bottom conditions (mud, gravel, sand, etc.). Certain shallower areas with muddy bottoms have mainly smaller birds where the minimum approach distance may be shortened. Smith and Bouwman (unpublished) conducted a study in 2004 to establish distribution patterns along the edge of the pan for conservation purposes. Their findings are presented in Appendix 1 (Figure 1-A1) and used to derive appropriate buffer zones. 
The shores of Barberspan are not homogenous. Combined with seasonal changes in water levels, a single approach to minimising disturbances will not be feasible. We propose the use of different approach distances for differing bird sizes, and buffer zones based on the average water level following the wet-season (September-March), assuming that most birds congregate at this interface. Buffer zones are set at the maximum FID per mass group, which is $104 \mathrm{~m}$ for small, $213 \mathrm{~m}$ for medium and $300 \mathrm{~m}$ for large birds. Rodgers and Smith (1995) suggested the buffer zones (or set-back distances) in Florida be set at $100 \mathrm{~m}$ for wading-bird colonies, and $180 \mathrm{~m}$ for tern and skimmer colonies. Their distances were calculated by adding the standard deviation to the mean from their sample, and then adding another $40 \mathrm{~m}$ to allow for the distances where the birds usually become agitated by a disturbance. Using a similar formula, Erwin (1989) suggested roughly the same distances. These distances were, however, for breeding colonies. Around foraging and loafing sites for most waterbirds in Florida, Rodgers and Smith (1997) suggested a buffer zone of about $100 \mathrm{~m}$. Borgmann (2011) suggested a buffer zone of $250 \mathrm{~m}$ for waterfowl, diving ducks, wading birds and shorebirds, to lessen the impact of human disturbance on sensitive or skittish species.

Considering what Smith and Bouwman (unpublished) found at Barberspan in 2004 (Appendix 1), we suggest that the medium- and large-bird buffer zones $(213 \mathrm{~m}$ and $300 \mathrm{~m}$, respectively) be used in areas with greater species richness, such as hotspots A, B and E (Figure 1-A1). Elsewhere, the small-bird buffer zone can be applied. It might, however, be somewhat impractical as birders might not be able to see the plovers and sandpipers at $104 \mathrm{~m}$. Therefore, we suggest that the small-bird buffer be set at the highest species mean FID for the group smaller than $200 \mathrm{~g}$, which is $62 \mathrm{~m}$ for the Blacksmith Lapwing Vanellus armatus. During the breeding season, the original buffer zone of $104 \mathrm{~m}$ may still be implemented in areas surrounding the breeding colonies. For practical reasons, the $300 \mathrm{~m}$ buffer for large birds is only applicable in areas where threatened and sensitive species occur regularly, as the highest mean FID for birds larger than $1000 \mathrm{~g}$ is still accounted for under the medium buffer. For the Goliath Heron and flamingos, being the largest species at Barberspan, we propose an individual minimum approach distance of the median FID $(127 \mathrm{~m})$ plus one standard deviation $(56 \mathrm{~m}$ ) be used for a more practical buffer of $183 \mathrm{~m}$.

There are several bird hides along the western shore of Barberspan and it is still preferable for tourists to use these facilities. Walking along the shore of the pan is allowed if size-class buffer zones are adhered to, while not disturbing the birds. The practical implementation of our proposals will need integration with the Barberspan management plan following consultations with the management and stakeholders. Information on appropriate buffer zones and sensitive areas can be provided at reception, and the distances can be indicated by representation of bird cut-outs at appropriate distances for birders to practice their distance estimations. The effectiveness of the memory retention of distances should, however, be tested.
Several factors in our study may be perceived as constraints. Firstly, we approached the birds directly on foot (simulating a threat), while a more oblique approach might result in shorter FIDs (Bateman \& Fleming 2011). Approach by vehicle, which may often be the case for birdwatchers in open habitat, would presumably have an influence on FID (McLeod et al. 2013). Another constraint may be that our observations were made outside the breeding season. Species that forage close to their nests (such as the Kittlitz's Plovers Charadrius pecuarius and Blacksmith Lapwings) may adjust their antipredator behaviours and FIDs, while birds that forage away from their nests, such as the herons, presumably would not or very little. For example, Møller et al. (2013a) found that FID was shortened for European bird species following harsh winter. We are also not aware of the effects of drought on FIDs, which could be a valuable future research area. The species distribution and biomass study (Smith \& Bouwman unpublished) was conducted 10 years prior to the flight initiation study. Distribution patterns and biomass could have changed over time. However, we believe the changes are not so profound as to disregard the information, as the conditions around the pan have not drastically changed.

\section{Conclusion}

This study has shown how flight initiation distances (FIDs) of waterbirds can be used to suggest management of bird sanctuaries such as Barberspan. Based on a combination of FIDs and spatial distribution around the pan, we propose approach distances for individual birds and buffer zones to be implemented around the pan according to the size of the birds (62 $\mathrm{m}$ and $183 \mathrm{~m}$ for small and larger species, respectively), and species diversity and richness of the area. Practical methods for implementation can be considered by the management and stakeholders of Barberspan. Future studies may focus on addressing the constraints mentioned in this study, such as repeating the FID measurements during the breeding season, the effects of the climate, and changes thereof, on the FID, as well as finding one or more predictive factors which birds, irrespective of species, may consider when perceiving and reacting to threats in their environment.

\section{Acknowledgements}

The authors thank MrS. van der Merwe, manager of Barberspan Bird Sanctuary, as well as Andrew Mvundle, Amos Koloti and Lebo Moeti, monitoring and research assistants from the reserve. The North West Parks and Tourism Board gave permission for this study. Opinions expressed and conclusions arrived at are those of the authors and are not necessarily to be attributed to the North West Parks and Tourism Board, or National Research Foundation. The authors thank the National Research Foundation of South Africa for funding.

\section{Competing interests}

The authors declare that they have no financial or personal relationships which may have inappropriately influenced them in writing this article. 


\section{Authors' contributions}

The study was conceived by H.B. and C.C. Fieldwork was done by C.C.C.C. and H.B. analysed the data and drafted the manuscript.

\section{References}

Bateman, P.W. \& Fleming, P.A., 2011, 'Who are you looking at? Hadeda Ibises use direction of gaze, head orientation, and approach speed in their risk assessment of a potential predator', Journal of Zoology 285, 316-323. https://doi. org/10.1111/j.1469-7998.2011.00846.x

Biggs, D., Turpie, J., Fabricius, C. \& Spenceley, A., 2011, 'The value of avitourism for conservation and job creation - An analysis from South Africa', Conservation and Society 9, 80-90. https://doi.org/10.4103/0972-4923.79198

Blumstein, D.T., 2003, 'Flight initiation distance in bird is dependent on intrude starting distance', The Journal of Wildlife Management 67, 852-857. https://doi. org/10.2307/3802692

Blumstein, D.T., 2006, 'Developing an evolutionary ecology of fear: How life history and natural history traits affect disturbance tolerance in birds', Animal Behaviour 71, 389-399. https://doi.org/10.1016/j.anbehav.2005.05.010

Blumstein, D.T., Anthony, L.L., Harcourt, R. \& Ross, G., 2003, 'Testing a key assumption of wildlife buffer zones: Is flight initiation distance a species specific trait?', Biological Conservation 110, 97-100. https://doi.org/10.1016/S0006-3207(02)00180-5

Borgmann, K.L., 2011, A review of human disturbance impacts on waterbirds, Audubon, CA, viewed 01 June 2016, from http://www.sfbayjv.org/news-general.php

Bouwman, H. \& Hoffman, R., 2007, 'The effects of fire on grassland bird communities of Barberspan, North West Province, South Africa', Ostrich 78, 591-608. https:// doi.org/10.2989/OSTRICH.2007.78.3.6.317

Cooper, W., 2005, 'When and how do predator starting distances affect flight initiation distances?', Canadian Journal of Zoology 83, 1045-1050. https://doi.org/10.1139/ z05-104

Del Hoyo, J., Elliot, A. \& Sargatal, J., 1992, Handbook of the birds of the world, vol. 1, Lynx Editions, Barcelona.

Del Hoyo, J., Elliot, A. \& Sargatal, J., 1996, Handbook of the birds of the world, vol. 3 , Lynx Editions, Barcelona.

Del Hoyo, J., Elliot, A. \& Sargatal, J., 2004, Handbook of the birds of the world, vol. 9, Lynx Editions, Barcelona.

Dugatkin, L.A., 2009, Principles of animal behaviour, 2nd edn., W.W. Norton \& Company, New York.

Erwin, R.M., 1989, 'Responses to human intruders by birds nesting in colonies: Experimental results and management guidelines', Colonial Waterbirds 12 104-108. https://doi.org/10.2307/1521318

Geist, C., Liao, J., Libby, S. \& Blumstein, D.T., 2005, 'Does intruder group size and orientation affect flight initiation distance in birds?', Animal Biodiversity and Conservation 28, 69-73.

Gill, J.A., Norris, K. \& Sutherland, W.J., 2001, 'Why behavioural responses may not reflect the population consequences of human disturbance', Biological Conservation 97, 265-268. https://doi.org/10.1016/S0006-3207(00)00002-1
Goering, D.K. \& Cherry, R., 1971, 'Nestling mortality in a Texas heronry', Wilson Bulletin 83, 303-305.

Hockey, P.A.R., Dean, W.R.J. \& Ryan, P.G. (eds.), 2005, Roberts birds of southern Africa, 7th edn., Trustees of the John Voelcker Bird Book Fund, Cape Town.

Kerbiriou, C., Le Viol, I., Robert, A., Porchar, E., Gourmelon, F. \& Julliard, R., 2009, 'Tourism in protected areas can threaten wild populations: From individual response to population viability of the chough Pyrrhocorax pyrrhocorax', Journa ofAppliedEcology46,657-665. https://doi.org/10.1111/j.1365-2664.2009.01646.x

Kullberg, C. \& Lafrenz, M., 2007, 'Escape take-off strategies in birds: The significance of protective cover', Behavioural Ecology and Sociobiology 61, 1555-1560. https://doi.org/10.1007/s00265-007-0387-1

Madsen, J., 1998, 'Experimental refuges for migratory waterfowl in Danish wetlands. I. Baseline assessment of the disturbance effects of recreational activities', Journal of AppliedEcology35(3),386-397.https://doi.org/10.1046/j.1365-2664.1998.00314.x

Mcleod, E., Guay, P.J., Taysom, A.J., Robinson, R.W. \& Weston, M.A., 2013, 'Buses, cars, bicycles, and walkers: The influence of the type of human transport on the flight responses of waterbirds', Public Library of Science 8, 1-12. https://doi.org/ 10.1371/journal.pone.0082008

Milstein, P.L., 1975, 'The biology of Barberspan, with special reference to the avifauna', Ostrich Supplement 10, 1-74.

Møller, A.P., 2010, 'Up, up and away: Relative importance of horizontal and vertical escape from predators for survival and senescence', Journal of Evolutionary Biology 23, 1689-1698. https://doi.org/10.1111/j.1420-9101.2010.02034.x

Møller, A.P. \& Erritzøe, J., 2010, 'Flight distance and eye size in birds', International Journal ofBehaviouralBiology116, 458-465. https://doi.org/10.1111/j.1439-0310. 2010.01754.x

Møller, A.P., Grim, T., Ibáñez-Álamo, J.D., Markó, G. \& Tryjanowski, P., 2013a, 'Change in flight initiation distance between urban and rural habitats following a cold winter', Behavioural Ecology 24(5), 1211-1217. https://doi.org/10.1093/beheco/ art054

Møller, A.P. \& Liang, W., 2012, 'Tropical birds take small risks', Behavioural Ecology 24(1), 267-272. https://doi.org/10.1093/beheco/ars163

Møller, A.P. \& Tryjanowski, P., 2014, 'Direction of approach by predators and flight initiation distance of urban and rural populations of birds', Behavioural Ecology 25(4), 1-7. https://doi.org/10.1093/beheco/aru073

Møller, A.P., Vagasi, C.I. \& Pap, P.L., 2013b, 'Risk-taking and the evolution of mechanisms for rapid escape from predators', Journal of Evolutionary Biology 26 , 1143-1150. https://doi.org/10.1111/jeb.12147

Ndlovu, M., Cumming, G.S., Hockey, P.A.R., Nkosi, M.D. \& Mutumi, G.L., 2013, 'A study of moult-site fidelity in Egyptian geese, Alopochen aegyptiaca, in South Africa', African Zoology 48(2), 240-249. https://doi.org/10.1080/15627020.2013.11407589

Nisbet, I.C.T., 2000, 'Disturbance, habituation and management of waterbird colonies', Waterbirds: The International Journal of Waterbird Biology 23(2), 312-332.

Rodgers, J.A., Jr. \& Smith, H.T., 1995, 'Set-back distances to protect nesting bird colonies from human disturbance in Florida', Conservation Biology 9(1), 89-99. https://doi.org/10.1046/j.1523-1739.1995.09010089.x

Rodgers, J.A., Jr. \& Smith, H.T., 1997, 'Buffer zone distances to protect foraging and loafing waterbirds from human disturbance in Florida', Wildlife Society Bulletin 25(1), 139-145.

Stankowich, T. \& Blumstein, D.T., 2005, 'Fear in animals: A meta-analysis and review of risk assessment', Proceedings of the Royal Society B 272, 2627-2634. https://doi. org/10.1098/rspb.2005.3251 


\section{Appendix 1}

Figure 1-A1 (presented here for illustration purposes) shows the mean species richness (a) and the mean biomass ( $b$ ) found along the western shores of the pan, measured over 3 months in 2004. The eastern shores were not measured, as this is the frequently disturbed, public angling area. The information in Figure 1-A1 allows for deriving appropriate protective buffer zones.

The species richness hotspot marked A (Figure 1-A1) is rarely disturbed by tourists and the bird hide is only accessible to visitors, while angling is prohibited in this area. The reeds and tall grass found here also make it a good breeding spot. Large areas of shallow water and exposed mud banks occur here. This is also where the highest biomass was found (Figure 1-A1b) as it is home to several duck and heron species, as well as spoonbills.
Hotspot B on Figure 1-A1 is a seasonal wetland and island (Goose Point), depending on water levels, restricting access at high water. During our study, the area could be approached on foot during March 2014, but not during the other 2 months. Both smaller waders and larger birds occur here.

Hotspots C-E (Figure 1-A1) are shallow bays and have some dense reed clumps growing on the banks, making it favourable for a large number of species to feed, breed and find shelter. The shores between $B$ and $E$ are often visited by birders, as well as resident antelope for drinking. These areas are prone to flooding and during flood events, it hosts higher species richness. The shores are overgrown with tall grass, limiting the number of waders. Hotspot $E$ is the least accessible part of the pan, despite the national road passing not far from there. It has dense reed stands and trees. This will account for the high preference of the birds to feed, breed and find shelter here, as can be seen in Figure 1-A1.

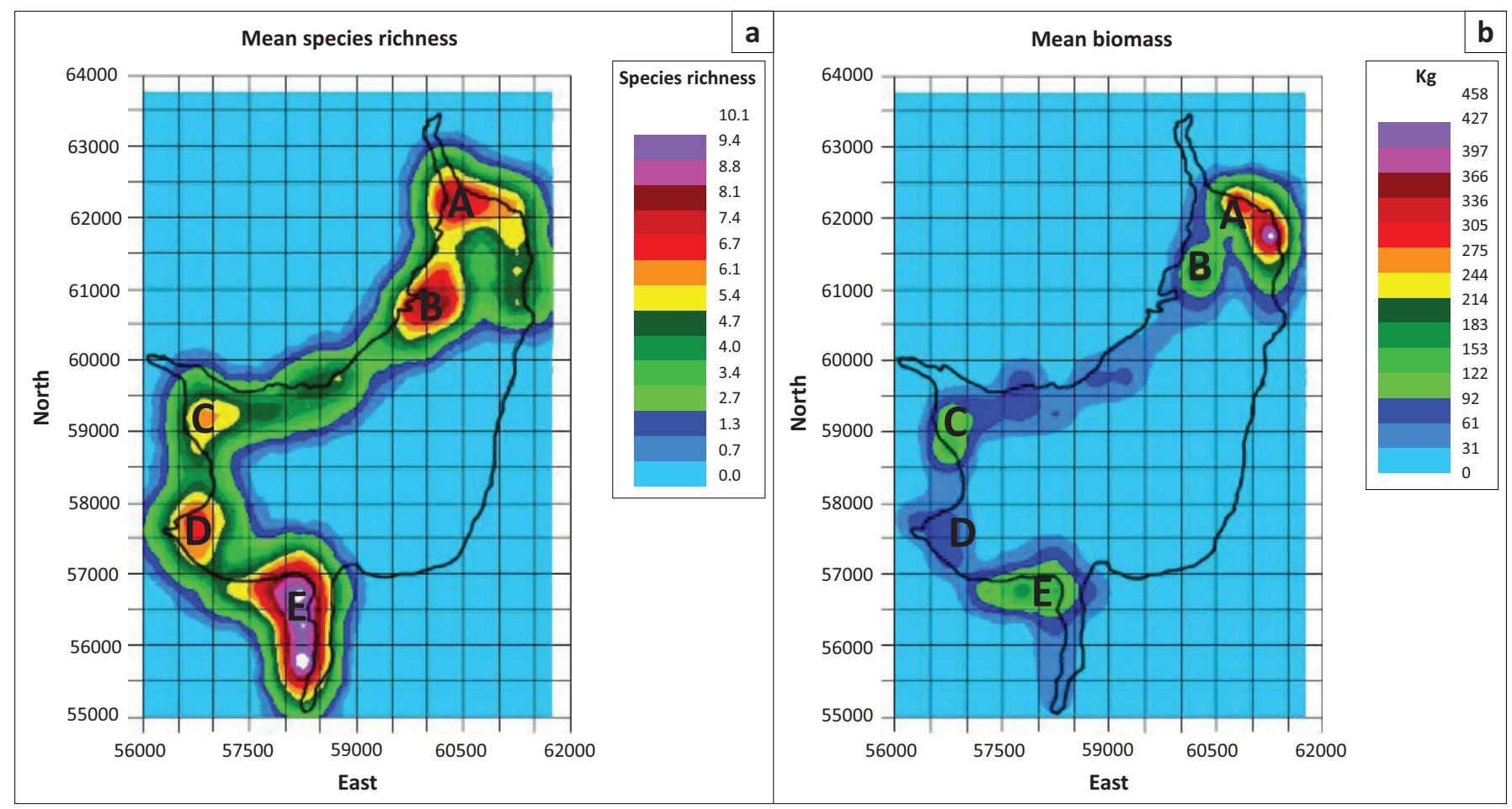

Source: Figure created by lan Smith (Smith \& Bouwman, unpublished), during a study titled: Aspects regarding the littoral distribution of Waterfowl at Barberspan Nature Reserve, North Wes Province, South Africa

Areas marked A-E represents the richness hotspots.

FIGURE 1-A1: Mean avian species richness (a) and biomass (b) along the western shore of Barberspan. 